\title{
Influence of Basic Variables on Micronucleii Frequency in General Population of FB \& H
}

\author{
Mirela Mačkić-Đurović ${ }^{1}$, Izeta Aganović-Mušinović ${ }^{1}$, Orhan Lepara ${ }^{2}$, Slavka Ibrulj $^{1}$ \\ Center for genetics, Faculty of medicine, University of Sarajevo, Cekalusa 90, 71000 Sarajevo, B\&H \\ Department of physiology, Faculty of medicine, University of Sarajevo, Cekalusa 90, 71000 Sarajevo, B\&H
}

\begin{abstract}
The aim of this study was to determine the value of micronuclei test (MN) on peripheral blood lymphocytes from 200 healthy participants of both gender from general population of $\mathrm{FB} \& \mathrm{H}$, as well as to determine if the gender, age or smoking habit have influence on MN frequency. Standard protocol for MN test cultivating and micronuclei analyzing from peripheral blood binuclear lymphocytes have been applied. Results have presented that range of singe values are from 0 to $8 \mathrm{MN}$ in 1000 binuclear cells. It has been determined that gender, age and smoking habit do have influence on MN frequency, especially on 2 MN frequencies. Females on average do have higher values of all variables of $M N$ test than men. It has been proven that smoking habit do have influence on increased number of cells with $2 M N$, as well. The results of this study will help to form data base as start for comparative research in future.
\end{abstract}

Keywords: micronuclei, age, gender, smoking habit

\section{Introduction}

Biological monitoring or bio- monitoring is an important tool in assessing either professional or environmental exposure to physical and chemical mutagens and/or carcinogens.

It is based on direct measurement of one's exposure to toxic substances in the environment by measuring the substances or their metabolites in human specimens, before the appearance of malignant and/or other diseases (1). The main postulate of making the effective and efficient use of biomarker knows its values in general, unexposed, healthy population.

Micronucleus test (MN) on peripheral blood lymphocytes is one of the most important methods employed in cytogenetic bio-monitoring. Besides MN-test, important are analyses of structural chromosomal aberrations (CA) and analyses of sister chromatid exchange (SCE), that are applied in observing professionally exposed populations. On molecular level is used comet assay was used for sensitive detection of the level of DNA damage (2). Chromosome aberrations are detected indirectly via chromatin loss from the nucleus leading to $\mathrm{MN}$ in the cytoplasm of the cell.

MN are defined as small additional nuclei, that contains DNA fragments, and are formed during cell division from rest of acentric chromosomal fragments or whole chromosome that are left during anaphase of cell cycle. In vitro $\mathrm{MN}$ test is reliable test for detection of mutagen factors (3). It is also reliable for genome instability detection that is related with increased risk of malignancies. Strong relationship between increased number of $\mathrm{MN}$ and some malignancies as with other disease (diabetes and cardiovascular disease) is evident (4, 5). All that justifies the use of $\mathrm{MN}$ test as suitable biomarker for long-term estimation of cytogenetic risk among human population.
The determination of most biomarkers requires the data base values of those parameters measured in the large group of general, healthy population.

Data base is recommended to be regenerated with fresh data (every two years); according to recommendation of field experts, it would be the best to have data of at least 20 people of each gender per decade of their age - which has been realized through this study (6).

The aim of this study is to determine the values of MN test from peripheral blood lymphocytes on 198 healthy people, both genders from general population of Federation of Bosnia and Herzegovina ( $\mathrm{F} \mathrm{BiH})$.

\section{Materials and Methods}

\subsection{Study Populations}

Study researches, as well as all procedures of blood sampling and handling in laboratory condition, and research results were according to ethical principles and directions for human population bio-monitoring. Examinees were informed of study aim; each examinee fulfilled questionnaire with the basic data needed for the study and signed his/her acceptance to enter the study.

Imperative was that examinees were from healthy general population that hadn't been exposed to physical or chemical agents, and that they didn't have any acute infection or medical exposures to named agents that could interfere with cytogenetic findings. 200 examinees entered the study: 20 of each gender per decade of their age. Two men had to be excluded from the study due to previous medical treatment.

Cytogenetic monitoring was performed on examinees that are residents of different areas in Federation of Bosnia and Herzegovina. 


\section{International Journal of Science and Research (IJSR) \\ ISSN (Online): 2319-7064 \\ Index Copernicus Value (2013): 6.14 | Impact Factor (2014): 5.611}

\subsection{Methods}

Standard protocol of $\mathrm{MN}$ test for cultivating and micronucleus analyzes from peripheral blood binuclear lymphocytes was applied. Blood samples were coded in accordance to residence place, than they were cultivated on RPMI 1640-PBmax media (Invitrogen) and incubated on $37^{\circ} \mathrm{C}$, 72 hours. At $44^{\text {th }}$ hour to cultures was added citohalasin B (Sigma) that disrupts cytoplasm division, but do not block nucleus division, and by that effect promotes appearance of binuclear lymphocytes in which are micronucleus are clearly seen. After incubation, microscopic slides were treated by standard procedure (5). Final slides were died in $10 \%$ Giemsa water solution (Sigma) and analyzed by light microscope (1000 x magnitude). Per each sample were analyzed 1000 binuclear lymphocytes and determined total number of $\mathrm{MN}$, number of cells with $\mathrm{MN}$ and their distribution (number in cells). Micronuclei were determined in accordance with recommended criteria HUMN (Human Micro Nucleus) (6).

\subsection{Statistics}

All variables were expressed as the medians and interquartile ranges for continuous data with or without a normal distribution, respectively. Binary logistic regression was used to analyze the influence of gender, age and smoking status on cells with $1 \mathrm{MN}$ or $2 \mathrm{MN}$ and how much is greater risk if any of the variables change. P-value $<0.05$ was considered statistically significant. All statistical analyses were performed using the computer software Statistical Package for the Social Sciences, version 20.0 (SPSS, Chicago, IL).

\section{Results}

The study population comprised of 198 participants, 98 males and 100 females divided each in 5 age groups (20-
29, 30-39, 40-49, 50-59, and 60-69). In the research category $\mathrm{MN}$ median is determined to be $(0,00-2,00)$, arth.median $1,05 \pm 0,07$, while the range of single values was from 0 to $8 \mathrm{MN}$ in 1000 binuclear cells. Median for cells with one $\mathrm{MN}$ ( $1 \mathrm{MN})$ is 2, 00, while fortwo $\mathrm{MN}$ $(2 \mathrm{MN})$ was 0,00 .

At 21 female and 25 male there were none $\mathrm{MN}$ found. Out of total female number $(\mathrm{n}=100)$, at 80 of them were found $1 \mathrm{MN}$. While at the male participants $(\mathrm{n}=98), 70$ of them had $1 \mathrm{MN}$.

$2 \mathrm{MN}$ were found at 22/100 female participants, and only $17 / 98$ at male participants. Correlation among gender and $\mathrm{MN}$, for cells with $1 \mathrm{MN}$ showed rho=0, $135 \mathrm{p}=0,059$, while for cells with $2 \mathrm{MN}$ showed rho=0, $170 \mathrm{p}=0,017$. From this can be concluded that the correlation among gender and $2 \mathrm{MN}$ is more significant than the one for 1 $\mathrm{MN}$.

When the statistical analyze was performed for smoking status and the number of $\mathrm{MN}$, it showed that smoking status and the number of cells with $1 \mathrm{MN}$ do not correlate $\mathrm{rho}=0,013 \mathrm{p}=0,859$. Percentage part of $1 \mathrm{MN}$ among smokers and non-smokers is equal. While smoking status and the number of cells with $2 \mathrm{MN}$ do correlate rho=0, 146 $\mathrm{p}=0$, 04. Percentage part of $2 \mathrm{MN}$ among smokers is larger, while the percentage part without $2 \mathrm{MN}$ was smaller.

Binary logistic regression was used to analyze the influence of gender, age and smoking status on cells with 1 MN (0-doesn't have; 1 has).

The age has statistical significance $p<0,0005$. For each additional year the risk to have $1 \mathrm{MN}$ (odds ratio) is increased for additional 12\%, 95\% CI (8-16\%) (Table 1).

Table 1: Analysis the influence of gender, age and smoking status on cells with $1 \mathrm{MN}$

\begin{tabular}{|c|c|c|c|c|c|c|c|c|c|}
\hline & & \multirow{2}{*}{ B } & \multirow{2}{*}{ S.E. } & \multirow{2}{*}{ Wald } & \multirow{2}{*}{ df } & \multirow{2}{*}{ Sig. } & \multirow{2}{*}{$\operatorname{Exp}(B)$} & \multicolumn{2}{|c|}{$95,0 \%$ C.I. for $\operatorname{EXP}(B)$} \\
\hline & & & & & & & & Lower & Upper \\
\hline \multirow{4}{*}{ Step 1(a) } & Gender & 656 &, 396 & 2,747 & 1 &, 097 & 1,926 &, 887 & 4,183 \\
\hline & Age & 109 & 018 & 36,305 & 1 &, 000 & 1,116 & 1,077 & 1,156 \\
\hline & Smoking Status & 741 &, 421 & 3,096 & 1 &, 078 & 2,098 &, 919 & 4,791 \\
\hline & Constant & $-4,443$ & ,990 & 20,159 & 1 &, 000 &, 012 & & \\
\hline
\end{tabular}

a Variable(s) entered on step 1: gender, age, smoking status

Binary logistic regression was used to analyze the influence of gender, age and smoking status on cells with 2MN (0-doesn't have; 1 has).

The most significant influence is related to age $p<0,0005$, follows smoking status $\mathrm{p}=0,010$ and on the end is gender $\mathrm{p}=0,019$.

For each additional year of age the risk to have $2 \mathrm{MN}$ is increasing for $6 \%, 95 \% \mathrm{CI}(3 \%-10 \%)$
If the non-smoker switch in category of smokers the risk to have $2 \mathrm{MN}$ (odds ratio) is increasing for 2, 8 times, 95\% CI (from1 to 6 times).

Females have $3 \times$ larger risk for $2 \mathrm{MN}, 95 \% \mathrm{CI}$ (from 1 to 6 times) (Table 2). 


\section{International Journal of Science and Research (IJSR) \\ ISSN (Online): 2319-7064}

Index Copernicus Value (2013): 6.14 | Impact Factor (2014): 5.611

Table 2: Analysis the influence of gender, age and smoking status on cells with $2 \mathrm{MN}$

\begin{tabular}{|c|c|c|c|c|c|c|c|c|c|}
\hline \multicolumn{2}{|c|}{} & \multirow{2}{*}{ B } & \multirow{2}{*}{ S.E. } & \multirow{2}{*}{ Wald } & \multirow{2}{*}{ df } & \multirow{2}{*}{ Sig. } & \multirow{2}{*}{ Exp(B) } & \multicolumn{2}{|c|}{$95,0 \%$ C.I.for EXP(B) } \\
\cline { 7 - 11 } & & & & & & Lower & Upper \\
\hline \multirow{4}{*}{ Step 1(a) } & gender &, 955 &, 409 & 5,457 & 1 &, 019 & 2,600 & 1,166 & 5,795 \\
\cline { 2 - 10 } & age &, 062 &, 016 & 14,259 & 1 &, 000 & 1,064 & 1,030 & 1,098 \\
\cline { 2 - 9 } & Smoking status & 1,040 &, 403 & 6,669 & 1 &, 010 & 2,828 & 1,285 & 6,225 \\
\cline { 2 - 9 } & Constant & $-6,300$ & 1,139 & 30,614 & 1 &, 000 &, 002 & & \\
\hline
\end{tabular}

a Variable(s) entered on step 1: gender, age, smoking status.

\section{Discussion}

Micronucleus from healthy population lymphocytes are indicator of genome damage of the single cell accumulated over the years, and the mutations that appears in the first in vitro cell division (1). Today, cytogenetics provides numerous different biomarkers for evaluating chromosomal instability and scoring of $\mathrm{MN}$ in lymphocytes is one that draws a lot of interest (7). In this study we have analyzed the level of cytogenetic damage in relatively healthy population from Bosnia and Herzegovina, both genders and within the range of age that is similar to one that is present at professionally exposed and actively working population, that could be controlled using MN-test, in the future. Upon evaluation of 5000 single person data from 23 world data base median value of $6,5 \mathrm{MN}$ on 1000 cells is established, the results were published in 2001 (8). Study of Milošević-Đorđević (7)on population of 164 participants, determined that the average is $(8,03 \pm 0,42)$ MNon 1000 cells. Similar results had got Kopjar (1), where analyzing 200 participants he determined the average $(6,90 \pm 3,32)$ MNon 1000 cells. Contrary to studies from literature, in our research we haven't count the total number of micronuclei $(1+2 \mathrm{MN})$ but they have been presented as number of cells with 1 $\mathrm{MN}$ and number of cells with $2 \mathrm{MN}$. Considering that this study was on healthy participants that hadn't been exposed to chemical and/or physical agents, and that they didn't have any acute infections and medical exposures in previous months that could influence the values of cytogenetic analyzes, we have minimized the influence of large number of environmental factors on single MN test values. That is why we have only considered gender, age and smoking status as factors that could have the biggest influence on $\mathrm{MN}(9,10)$.

Our research, as well as others presented that females do have more $\mathrm{MN}$ than males, in average (8). According to Fenech (11) the frequency of $\mathrm{MN}$ at females is larger 1.2 up to 1,6 times. In this research is presented that females could have up to 3 times more cells with $2 \mathrm{MN}$ than males, while this ratio is smaller when $1 \mathrm{MN}$ is considered. One of the reasons why females do have increased frequency of $\mathrm{MN}$ is the loose of one of $\mathrm{X}$ chromosomes through $\mathrm{MN}$ $(12,13)$. Positive correlation among $\mathrm{MN}$ frequency and the age is declared in many studies $(14,15)$. According to our data, just age had statistical significance when considered $1 \mathrm{MN}$, as well as considered cells with 2MN.The research showed that for each additional year of age the risk to increase the number of cells with $2 \mathrm{MN}$ is $6 \%, 95 \% \mathrm{CI}$, while that percentage is larger $12 \%$ considering cells with $1 \mathrm{MN}$. Research of Orta shows the increase in the frequency of micronuclei was first observed up to 50 years of age and this increase were followed by a decrease with a further increasing age. Milosevic-Djordjevic(7) showed a decrease of $\mathrm{MN}$ frequencies in older aged groups and explained this might be the result of declining in proliferation capacity of cells with an increasing age, as well. Norppa and Falck based upon extensive results analyzes of numerous studies conclude that $30 \%$ to $80 \%$ of spontaneously arisen MN comprise whole chromosomes. In contrast to sex chromosomes that are more often lost through $\mathrm{MN}$, autosomes in $\mathrm{MN}$ appear randomly and cannot be lost only by ageing $(17,18)$. It's also been noticed that apparently healthy people could have large number of $\mathrm{MN}$ in who is prevalent a specific chromosome (1).

One of the important factors that influence on $\mathrm{MN}$ is smoking. According to some studies the smoking is increasing the number of $\mathrm{MN}(19,20)$, part of research did not established such relation (21). Our results presented that there were no statistic significant difference among smokers and $\mathrm{MN}$, if $1 \mathrm{MN}$ cells are considered. However, by use of binary logistic regression it is established that the smoking status influence on increased number of $2 \mathrm{MN}$ cells. Accordingly, if the non-smoker become smoker the chance for $2 \mathrm{MN}$ appearances is increased for 2, 8 times, 95\% CI (from 1 to 6 times). Although, the smoking status did not influence on increased $\mathrm{MN}$ number in all studies, still should be considered in interpreting $\mathrm{MN}$ test analyzes since mutagens and genotoxic compound that arises during smoking of cigarettes could have synergic effects with other environmental agents, which has to be in consideration when questioning professionally exposed population (1).Upon present experience and knowledge, MN test has great advantage over rest of cytogenetic tests since it allows damage estimation on function level and integration of dividing spindle, that other methods cannot do (12). It should be pointed out that MN-test is useful in genome instability discovery that is put in relation with increased cancer risk (22). According to Bonassi research this study provides preliminary evidence that $\mathrm{MN}$ frequency in PBL is predictive of cancer risk, suggesting that increased $\mathrm{MN}$ formation is associated with early events in carcinogenesis (23).

\section{Conclusion}

Results of MN test according to age, gender and smoking status from this study are in accordance with results determined on general healthy population in other laboratories. These results will allow forming research data base for multiple genetic categorization and as the base for comparing and interpreting analyzes in further research projects, medical diagnostics, control and bio-monitoring 


\section{International Journal of Science and Research (IJSR) \\ ISSN (Online): 2319-7064 \\ Index Copernicus Value (2013): 6.14 | Impact Factor (2014): 5.611}

for professionally and environmentally exposed populations and others, where is applied character of this research, as well as the base for further development of laboratory data base.

\section{References}

[1] Kopjar N, KašubaV, Milić M, Rozgaj R, Želježić D, Gajski G, Mladinić M, Garaj-Vrhovac V. Micronucleus assay in Croatian general population. ArhHig Rada Toksikol 2010;61:219-234

[2] Collins AR. The comet assay for DNA damage and repair: principles, applications, and limitations. MolBiotechnol 2004;26:249-61.

[3] Krishnaja AP, Sharma NK. Transmission of $\gamma$ - ray induced unstable chromosomal aberrations through successive mitotic divisions in human lymphocytes in vitro. Mutagenesis 2004;19(4): 295-305.

[4] Fenech M. The cytokinesis-block micronucleus technique: a detailed description of the method and its application to genotoxicity studies in human populations. Mutat Res 1993;285:35-44.

[5] Fenech M. Cytokinesis-block micronucleus cytome assay. Nature Protocols 2007;2:1084-104.

[6] Fenech M, Cgang WP, Kirsch-Volders M, isar. Human Micronucleus project, "HUMN project: detailed description of the scoring criteria for the cytokinesis-block micronucleus assay using isolated human lymphocyte cultures". Mutat Res. 2003;534:65-75

[7] Milosevic-Djordjevic O, Grujicic D, Novakovic T, Arsenijevic S, Marinkovic D. Micronuclei and ageing in a sample of Yugoslavian population. Russ J Genet 2002;38:201-4.

[8] Bonassi S, Fenech M, Lando C, Lin Y, Ceppi M, Chang WP, Holland N, Kirsch-Volders M, Zeiger E, Ban S, BaraleR, Bigatti MP, Bolognesi C, Jia C, Di Giorgio M, Ferguson LR, Fučić A, Garcia Lima O, Hrelia P, Krishnaja AP, Lee T-K, Migliore L, Mikhalevich L, Mirkova E, Mosesso P, Muuller W-U, Odagiri Y, Scarfo MR, Szabova E, Vorobtsova I, Vral A, Zijno A. HUmanMicroNucleus Project: International database comparison for results with the Cytokinesis-Block Micronucleus Assay in human lymphocytes: I. Effect of laboratory protocol, scoring criteria, and host factors on the frequency of micronuclei. Environ Mol Mutagen 2001; 37:31- 45.

[9] Albertini RJ, Nicklas JA, O’Neill JP. Future research directions for evaluating human genetic and cancer risk from environmental exposures. Environ Health Persp 1996; 104(Suppl 3):503-10.

[10] Battershill JM, Burnett K, Bull S. Factors affecting the incidence of genotoxicity biomarkers in peripheral blood lymphocytes: impact on design of biomonitoring studies Mutagenesis 2008; 23:423-37.

[11]Fenech M. Important variables that influence base-line micronucleus frequency in cytokinesis-blocked lymphocytesa biomarker for DNA damage in human populations. Mutat Res 1998; 404:155-65.

[12] Bolognesi C, Lando C, Mateuca R, Lombaert N, Aka PV, Decodier I, Kirsch-Volders, M. Chromosomal changes: induction, detection methods and applicability in human biomonitoring. Biochemie 2006; 88:1515-31.

[13] Kažimirova A, Barančokova M, KrajčovičovaKudlačkova M, Volkovova K, Staruchova M, Valachovičova M, Paukova V, Blažiček P, Wsolova L, Dušinska M. The relationshipbetween micronuclei in human lymphocytes and selected micronutrients in vegetarians and non-vegetarians.Mutat Res 2006; 611:64-70.

[14] Veerachari U, VenkateshSh, Yadav A, Narayanappa R. Biomonitoring genetic instability in normal healthy population using a simple cytogenetic marker for micronucleus test. International Multidisciplinary Research Journal 2011, 1/2:01-09

[15] Catalan J, Autio K, Kuosma E, Norppa H. (1998). Agedependent inclusion of sex chromosomes in lymphocyte micronuclei of man. Am. J. Hum. Genet. 63, 1464-1472.

[16] Tuncay O, Süreyya G.The effect of aging on micronuclei frequency and proliferation in human peripheral blood lymphocytes.Indian J Human Genet. 2012 Jan-April; 18(1):95-100.

[17] Norppa H, Falck GCM. What do human micronuclei contain? Mutagenesis 2003; 18:221-33.

[18] Scarpato R, Landini E, Migliore L. Acrocentric chromosome frequency in spontanous human lymphocyte micronuclei, evaluated by dual colour hybridization, is neither sex- nor age related. Mutat Res 1996; 372:195-204.

[19] Schneider M, Diemer K, Engelhart K, Zankl H, Trommer WE, Biesalski HK. Protective effects of vitamins $\mathrm{C}$ and $\mathrm{E}$ on the number of micronuclei in lymphocytes of smokers and their role in ascorbate free radical formation in plasma. Free Radic Res 2001;34:209-19.

[20] Duffaud F, Orsiere T, Villani P, Pelissier AL, Volot F, Favre R, Botta A. Comparison between micronucleated lymphocyte rates observed in healthy subjects and cancer patients. Mutagenesis 1997; $12: 227-31$.

[21] Hoffmann H, Speit G. Assessment of DNA damage in peripheral blood of heavy smokers with the comet assay and the micronucleus test. Mutat Res 2005;581:105-14.

[22] Fenech M, Crott JW. Micronuclei, nucleoplasmic bridges and nuclear buds induced in folic acid deficient human lymphocytes-evidence for breakagefusion-bridge cycles in the cytokinesis-block micronucleus assay. Mutat Res 2002; 504:131-6.

[23] Bonassi S, Znaor A, Ceppi M, Lando C, Chang WP, Holland N, Kirsch-Volders M, Zeiger E, Ban S, Barale R, Bigatti P, Bolognesi C, CebulskaWasilewska A, Fabianova E, Fučić A, Hagmar L, Joksić G, Martelli A, Migliore L, Mirkova E, Scarfi MR, Zijno A, Norppa H, Fenech M. An increased micronucleus frequency in peripheral blood lymphocytes predicts the risk of cancer in humans. Carcinogenesis 2007;28:625-31 